\title{
The ovarian follicular wave pattern in the mated and non-mated dromedary camel (Camelus dromedarius)
}

\author{
J. A. Skidmore ${ }^{1,2}$, M. Billah ${ }^{1}$ and W. R. Allen ${ }^{2 *}$ \\ ${ }^{1}$ The Camel Reproduction Laboratory, Nakhlee, Dubai, UAE; and ${ }^{2}$ TBA Equine Fertility Unit, \\ Mertoun Paddocks, Woodditton Road, Newmarket, Suffolk CB8 9BH. UK
}

\begin{abstract}
Introduction
The one-humped camel (Camelus dromedarius) is an induced ovulator with a relatively short mating period, during which ovarian activity is increased (Novoa, 1970). If mating does not occur, follicles regress after initial periods of growth and maturity and, for this reason, it is more appropriate to use the term 'follicular wave pattern' than oestrous cycle in this species. All previous studies on folliculogenesis in camels have used palpation of the ovaries per rectum in small groups of animals and have given conflicting results. For example, the duration of the follicular wave is reported as 17-23 days in India (Joshi et al., 1978), 24 days in Egypt (Wilson, 1984) and 28 days in Sudan (Musa and Abusineina, 1978). The present study used serial transrectal ultrasound examinations of the ovaries of a large group of female camels to define the kinetics of the follicular wave pattern more accurately and relate these changes to oestrous behaviour and steroid hormone concentrations in peripheral serum.
\end{abstract}

\section{Materials and Methods}

A total of 36 healthy, female camels, free from any uterine and ovarian abnormalities and aged between 5 and 14 years, were divided into three groups and examined on alternate days from the beginning of November to the beginning of January. Group $1(n=20)$ animals were teased with a vasectomized male for 20 min each day but mating was prevented. Group $2(n=8)$ animals ran freely with a vasectomized male for $10 \mathrm{~h}$ each day for 8 weeks when they were watched for signs of oestrous behaviour and matings. Group $3(n=8)$ animals were kept out of sight, sound and smell of any male camels. The ovaries of all the camels were examined on alternate days for at least two complete 'waves', by transrectal ultrasonography using an Aloka Model 500 realtime scanner with a $5 \mathrm{MHz}$ linear array transducer (Skidmore et al., 1992). All the follicles and corpora lutea were counted and measured using the internal electronic calipers.

Daily jugular vein blood samples ( $10 \mathrm{ml}$ ) were recovered from all camels throughout the experimental period. They were centrifuged at $1000 \mathrm{~g}$ for $5 \mathrm{~min}$ within $2-4 \mathrm{~h}$ of collection and the serum decanted and assayed subsequently for progesterone concentrations in a chemiluminescent assay kit (Amerlite Progesterone Assay; Kodak Clinical Diagnostics, Amersham). This used a competitive immunoassay technique based on enhanced luminescence (Whitehead et al., 1983) and the antibody showed crossreactivities of $5.2 \%, 4.17 \%$ and $1.1 \%$ with $5 \alpha$-pregnane-3,20-dione, $5 \beta$-pregnane-3,20-dione and $20 \alpha$-dihydroprogesterone, respectively. The limit of sensitivity of the assay was $0.11 \mathrm{ng} \mathrm{ml} \mathrm{m}^{-1}$ serum, $_{\text {, }}$ and the inter- and intra-assay coefficients of variation were $8.0 \%$ and $7.5 \%$, respectively.

To investigate the possible association between number of follicles and diameter of the largest follicle, two statistical tests were performed. The product-moment correlation coefficient $(r)$ and, to confirm the result, the equivalent rank coefficient (Kendall's; Tau) were calculated.

\section{Results}

In Groups 1 and 3, the follicular cycle varied considerably between individual camels but was nevertheless clearly divisible into three phases: the growth phase that lasted a mean ( \pm SD) of $10.9 \pm 3.0$

*Correspondencé 


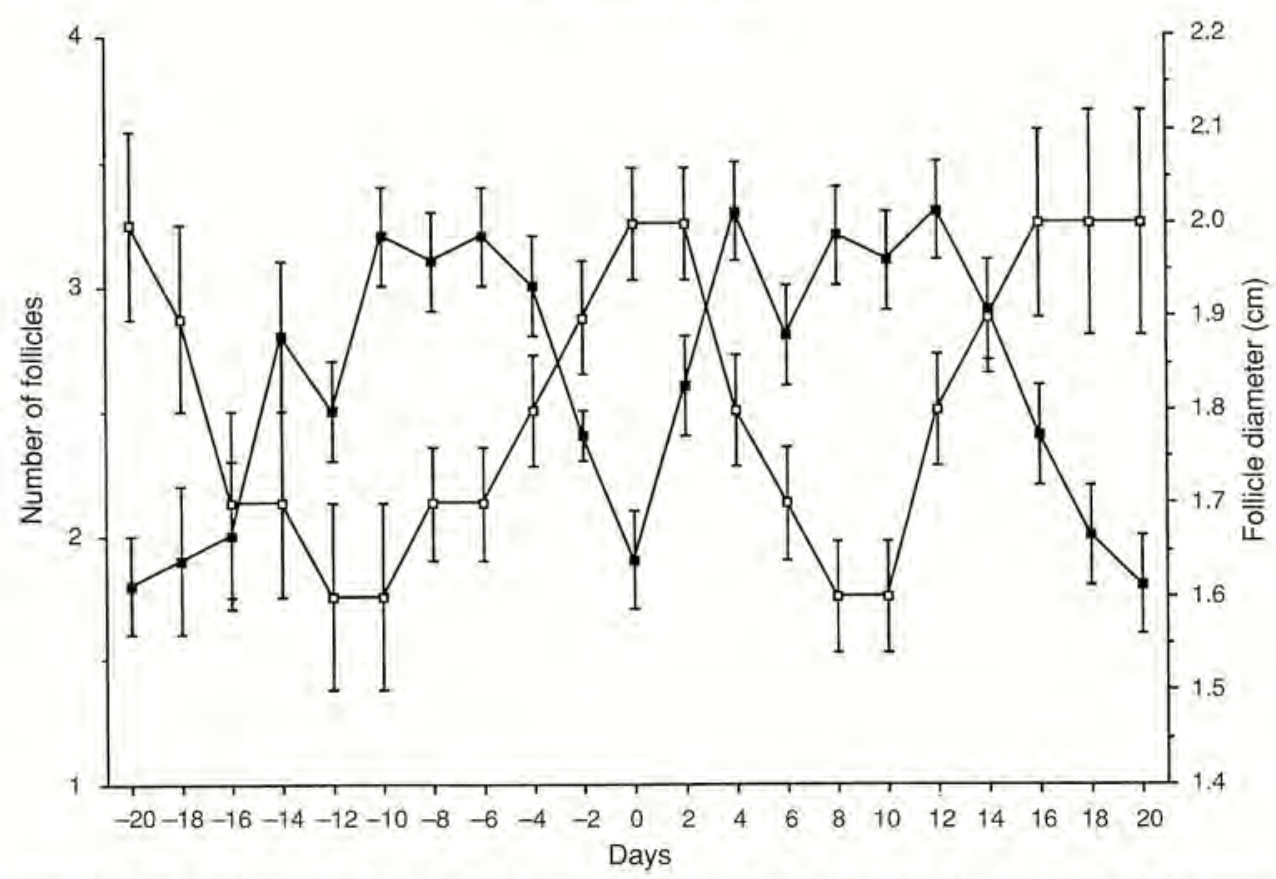

Fig. 1. Inverse relationship between the mean ( \pm SEM) number of follicles detected $(-)$ and the mean ( \pm SEM) diameter ( $\mathrm{cm}$ ) of the largest follicle ( $\mathrm{c}$ ). Results represent pooled data from Group 1 and Group 3. Day 0 is the day the dominant follicle reached maximum diameter $(n=28)$.

days; a mature phase of $7.6 \pm 4.2$ days; and, a regressing phase of $11.9 \pm 4.2$ days. No spontaneous ovulations occurred in either group. The mature follicle reached a mean maximum diameter of $2.0 \pm 0.3 \mathrm{~cm}$ in $52 \%(n=34)$ of the cycles studied before it regressed as expected. However, in the other $48 \%(n=32)$ of cycles, it continued to grow to $4.2 \pm 0.9 \mathrm{~cm}$. These oversized follicles took $18.4 \pm 4.2$ days to grow to full diameter, remained at the same size for $4.6 \pm 2.6$ days and then took $15.3 \pm 6.1$ days to regress completely. To determine whether follicular activity occurred in waves, the mean number of follicles in both ovaries, from 20 days before to 20 days after the reference point, was tabulated in relation to the diameter of the largest follicle (Fig. I). The day this reached its maximum diameter was taken as the common reference point (day 0 ) because a day of ovulation was not available in the anovulatory group. There was a strong negative association between the number of follicles and the diameter of the largest follicle with a product moment correlation coefficient of $r=-0.627 \quad(P<0.003)$. Kendall's coefficient of rank correlation confirmed this conclusion (tau $=-0.467 ; P<0.004)$.

In Group 2, the female camels were mated when the dominant follicle reached a mean $( \pm \mathrm{SD})$ diameter of $1.3 \pm 0.2 \mathrm{~cm}$. The mean interval between two matings was $13.8 \pm 3.3$ days. New follicles became visible $5.1 \pm 1.7$ days after the first mating and took $8.3 \pm 4.2$ days to mature to $1.3 \mathrm{~cm}$ in diameter, at which time the camel was remated. The corpus luteum had a lifespan of $8.5 \pm 1.4$ days, as reflected by serum progesterone concentrations that remained low $\left(<0.5 \mathrm{ng} \mathrm{ml}^{-1}\right)$ for the first 3 days after ovulation (day 0) and then rose steadily to a mean peak value of $2.6 \mathrm{ng} \mathrm{ml}^{-1}\left(1.6-4.8 \mathrm{ng} \mathrm{ml}^{-1}\right.$ ) on day 7 or 8 , before falling sharply on day 9 or 10 to reach a mean value of $<0.5 \mathrm{ng} \mathrm{ml}^{-1}$ again on day 10-12. Progesterone concentrations in the non-mated group remained low $\left(0.1-0.4 \mathrm{ng} \mathrm{ml}^{-1}\right.$ ) throughout the experimental period (Fig. 2).

Signs of oestrus in the females were vague and highly variable in both groups and seemed to bear little relationship to follicular maturity. Only twice did the female submit quietly to the male and squat in front of him. More often the male would select one female and chase her until she submitted and allowed him to mate. 


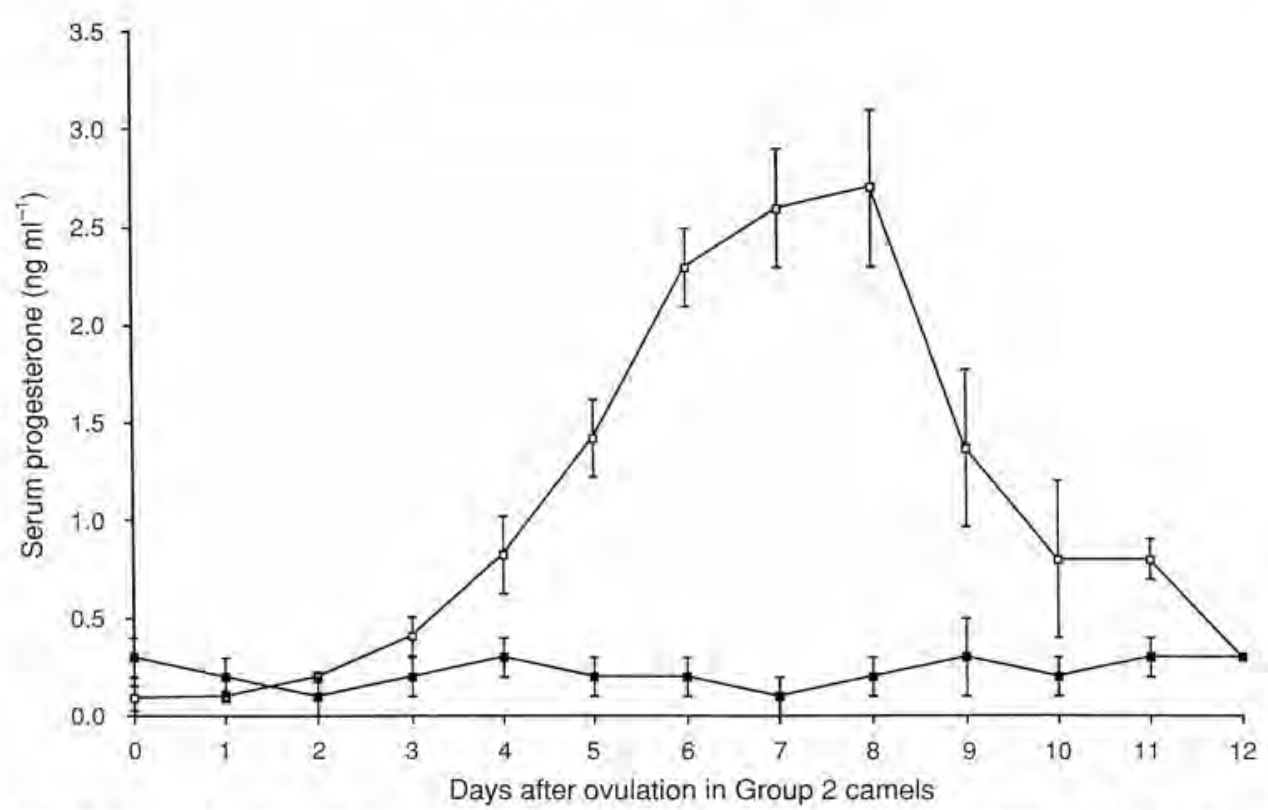

Fig. 2. Mean ( \pm SEM) serum progesterone concentrations in mated $(a ; n=8)$ and non-mated $(\mathbf{*} n=28)$ camels. Day 0 is the day of ovulation in Group 2 camels.

\section{Discussion}

Waves of follicular activity in the camel were indicated by periodic increases in the number of follicles detected and an associated emergence of a dominant follicle that grew to a mean maximum diameter of $2.0 \mathrm{~cm}$, while the other follicles regressed. Furthermore, the inverse relationship between the diameter of the largest follicle and number of follicles was consistent with the follicular wave theory (Ginther et al, 1989; Adams et al., 1990).

The mature follicle was smaller in the mated group $(1.3 \pm 0.2 \mathrm{~cm})$ compared with the $1.5-2.5 \mathrm{~cm}$ mature follicle in the two nonmated groups. This suggests that the follicle is mature enough to ovulate before it has reached maximum size. No overlarge follicles of $\geq 3 \mathrm{~cm}$ developed in any Group 2 camels, presumably because they were mated as the dominant follicle matured and the resulting ovulation prevented any further growth. In Group 1 and Group 3 camels, when the dominant follicle grew $\geq 3 \mathrm{~cm}$ diameter, scattered free floating echogenic strands developed within the follicular fluid and became more organized into fibrinous bands as the follicle degenerated. However, these overlarge follicles did not interfere with the growth of smaller follicles in the same or opposite ovary, which matured and even ovulated if the appropriate stimulus was applied. Similar oversized follicles have been described in the llama that, at ovariectomy, were found to be haemorrhagic, thin walled and lacking an ovulatory stigma. All 13 haemorrhagic follicles studied were the dominant follicle of a wave during which no copulatory stimulus had been applied (Adams et al., 1991).

Peripheral serum progesterone profiles in the two nonmated groups showed that no spontaneous ovulations occurred, even in the presence of a male camel. Profiles in the mated group showed that luteolysis began between day 8 and day 9 after ovulation and was complete by day 11 (Fig. 2). This agrees with the figures reported by Marie and Anouassi (1987) for the dromedary and Xu ef al. (1985) for the Bactrian camel.

As the mean interval between two successive matings was only 13 days, the new wave of follicular growth must start during the luteal phase for the dominant follicle to be mature enough for the female to be re-mated as soon as luteolysis is complete. Therefore, mating and subsequent ovulation causes a shortening of the interwave interval from a mean ( $\pm \mathrm{SD}$ ) of $18.2 \pm 3.8$ days in nonmated camels to $13.8 \pm 3.3$ days in mated animals. It is likely that the rapid decline in progesterone secretion rate which 
results from luteolysis at the end of dioestrus acts to initiate and hasten the new wave of follicular growth.

In conclusion, follicular wave patterns may vary considerably between individual camels, but all comprise definite growth, mature and regression phases. The interwave interval is approximately 18 days in nonmated camels, but is reduced drastically to around 13 days if the camels are mated. The frequent occurrence of large unovulated follicles appears to result from the current management practice of keeping male and female camels apart.

\section{References}

Adams GP, Sumar J and Ginther OJ (1990) Effect of lactational and reproductive status on ovarian follicular waves in llama (Llama glama) Journal of Reproduction and Fertility 90 535-545

Adams GP, Sumar J and Ginther OJ (1991) Haemorrhagic ovarian follicles in llamas Theriogenology 35 557-568

Ginther OJ, Knopf L and Kastelic JP (1989) Temporal associations among ovarian events in cattle during oestrous cycles with two and three follicular waves Journal of Reproduction and Fertility 87 223-230

Joshi CK, Vyas KK and Pareek PK (1978) Studies on the oestrous cycle in Bikaneri she-camels Indian Journal of Animal Science 48 141-145

Marie M and Anouassi A (1987) Induction of luteal activity and progesterone secretion in the non-pregnant one-humped camel (Camelus dromedarius) Journal of Reproduction and Fertility 80 183-192

Musa BE and Abusineina ME (1978) The oestrous cycle of the camel (Camelus dromedarius) Veterinary Record 103 556-557
Novoa C (1970) Reproduction in the Camelidae: a review Journal of Reproduction and Fertility 22 3-20

Skidmore JA, Billah M and Allen WR (1992) Ultrasonographic and videoendoscopic monitoring of early fetal development in the dromedary camel In Proceedings of the First International Camel Conference pp 193-202 Eds WR Allen, AJ Higgins, IG Mayhew, DH Snow and JF Wade. R \& W Publications, Newmarket

Whitehead TP, Thorpe EHG, Carter JN, Groucutt C and Kricka LJ (1983) Enhanced luminescence procedure for sensitive determination of peroxidase-labelled conjugates in immunoassay Nature 305 158-159

Wilson RT (1984) Reproduction and breeding. In The Camel pp 83-101. Longman, London

Xu YS, Wang HY, Zeng GQ, Jiang GT and Gao YH (1985) Hormone concentrations before and after semen-induced ovulation in the Bactrian camel (Camelus Bacterianus) Journal of Reproduction and Fertility 74 341-346 